\title{
Is robotic approach more suited for thoracic procedures than video-assisted thoracic surgery (VATS)?
}

Conventional thoracic incisions are associated with significant pain and morbidity. Historically thoracic procedures required prolong hospital stay and recovery time. Minimally invasive approaches, initially video-assisted thoracic surgery (VATS) and recently the robotic approach, have offset these morbidities without compromising the technical and oncological principles of thoracic surgery. Thorax is particularly suited for robotic surgery due to its fixed space and critical structures. The robotic approach due to its enhanced 3D visions, dexterity, wrist like articulations of the instruments and tremor filtrations provides an unparallel opportunity for meticulous dissection and intracorporeal suturing. Globally there is a rising adoption of robotic approach for surgical management of benign and malignant esophageal conditions, and lung and mediastinal tumor resection. Complex lung resections like sleeve lobectomy and segmentectomies are better performed via robotic approach with less conversion to thoracotomy as compare to conventional VATS approach. Similarly, radical thymectomy can be performed via unilateral chest approach using the robot as compare to the necessity of bilateral thoracic approach in VATS. Additionally, robot is superior in operating in difficult to access human body areas such as thoracic inlet. Robotic approach for resection of first rib, proximal esophageal tumors and neurogenic tumors has become the preferred minimally invasive approach. As the robotic platforms continue to evolve, more complex thoracic surgical interventions will be facilitated, translating to improved outcomes for our patients.

In this focused issue of the fournal of Thoracic Disease, world leaders in robotic thoracic surgery have provided an update on these common thoracic procedures to elucidate the indications and techniques for the readers.

\section{Acknowledgments}

Funding: None.

\section{Footnote}

Provenance and Peer Review: This article was commissioned by the editorial office, Fournal of Thoracic Disease for the series "Robotic Thoracic Surgery". The article did not undergo external peer review.

Conflicts of Interest: The author has completed the ICMJE uniform disclosure form (available at http://dx.doi.org/10.21037/ jtd-21-772). The series "Robotic Thoracic Surgery" was commissioned by the editorial office without any funding sponsorship. GA served as the unpaid Guest Editor of the series and serves as an unpaid editorial board member of fournal of Thoracic Disease. The author has no other conflicts of interest to declare.

Ethical Statement: The author is accountable for all aspects of the work in ensuring that questions related to the accuracy or integrity of any part of the work are appropriately investigated and resolved.

Open Access Statement: This is an Open Access article distributed in accordance with the Creative Commons AttributionNonCommercial-NoDerivs 4.0 International License (CC BY-NC-ND 4.0), which permits the non-commercial replication and distribution of the article with the strict proviso that no changes or edits are made and the original work is properly cited (including links to both the formal publication through the relevant DOI and the license). See: https://creativecommons.org/ licenses/by-nc-nd/4.0/. 


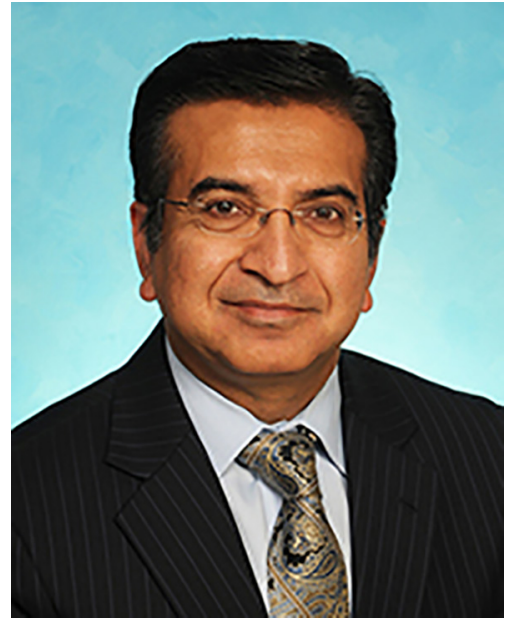

Ghulam Abbas

Ghulam Abbas, MD, MHCM, FACS

Department of Cardiovascular and Thoracic Surgery, West Virginia School of Medicine, Morgantown, WV, USA. (Email: ghulam.abbas@bsc.wvu.edu) Submitted May 03, 2021. Accepted for publication May 24, 2021. doi: $10.21037 /$ jtd-21-772 View this article at: http://dx.doi.org/10.21037/jtd-21-772

Cite this article as: Abbas G. Is robotic approach more suited for thoracic procedures than video-assisted thoracic surgery (VATS)? J Thorac Dis 2021;13(10):6111-6112. doi: 10.21037/ jtd-21-772 